\title{
Sciendo
}

DOI: $10.2478 /$ jolace-2019-0017

\section{Teaching Slovak Language and Literature in the 1st Grade of Grammar Schools: the Verification of the Development of Critical Thinking of Pupils}

\author{
Martina Kosturková \\ University of Presov, Slovakia \\ martina.kosturkova@unipo.sk
}

\begin{abstract}
Slovak language and literature belongs to the leading subjects in the system of secondary education in the Slovak Republic. The persistent traditional teaching techniques (encyclopedic-memorization) and the absence of systematic development of critical thinking in the process of education has caused an identified below average state of critical thinking of students at secondary grammar schools. The aim of our half-year experiment was to verify the effectiveness of The Programme of Development of Critical Thinking of Pupils in the Subject of Slovak Language and Literature. To meet the set target we implemented an experiment (a single-factor technique of parallel groups). Out of 16 firstgrade secondary grammar schools classes $(N=365)$ two equivalent groups were selected for the experiment - an experimental group $(n=32)$ and a control group $(n=30)$. The main measurement means was the Watson-Glaser Critical Thinking Appraisal Test. The conclusions of the experiment pointed out the effectiveness of the intervention programme.

Keywords: critical thinking, research findings, the experimental verification of the development of critical thinking of pupils.

\section{Introduction}

The experts dealing with the quality of educational process have been, for a longer time, aware of the importance of the ability to think critically. Such an ability has been identified in 21th century as one of the learning and innovative skills necessary for life. Critical thinking is a part of the requirements of Dublin Descriptors, the European and National Qualifications Framework of the Slovak Republic, the Programme for International Student Assessment OECD PISA, but it is also one of the most required qualities defined by the World Economic Forum in Davos 2015.

Despite the prolong requirements the area of critical thinking has been at the periphery of the Slovak education system. The necessity to develop this ability has already been alerted by the analyses of OECD PISA international reviews, which Slovakia participated in for the first time in 2003. The experts notified that Slovak
\end{abstract}


15-year-old pupils had the biggest problems with the tasks which required the need to apply critical thinking assessment. Inspite of appropriate precautions made in advance and the development of critical thinking incorporated in the State Education Programme of the Slovak Republic (SEP SR) as one of the target requirements, the application in the educational process remained just as an effort of a few individuals.

The identified below average status of critical thinking of grammar school students from the eastern region of Slovakia ( $N=365 ; M=40.41$ out of 80 points) was the reason to elaborate the programme of development of critical thinking in the subject of Slovak language and literature in 1st grade of four-year grammar schools. The presented study focuses on the task of the verification of the effectiveness of this programme which, in practice, lasted for 5 months. While conceiving the issue we used the findings of several foreign and domestic authors, who came to the conclusion that critical thinking is not inborn, but it appears and develops by the systematic impact and activation of the subject (Hill, 1959; Ennis, 1962; Glaser, 1963; Sternberg, 1987; Facione, 1990; Gavora, 1995; Watson \& Glaser, 2000; Petrasová, 2008; Marin \& Halpern, 2011).

\section{Discussion of the concept of critical thinking}

Since foreign sources offer a definition of critical thinking in three lines philosophical, psychological and educational, the diversity of understanding of this term led to a sharp debate. Leading experts thus tried several times to find their common features and they finally succeeded at the end of 20th century after a constructive debate. Consequently the world's experts agreed on the cognitive areas that should be included in the definition of critical thinking. Lai (2011) outlines the following overview of the components of the definition of critical thinking:

- analyzing arguments, claims, or evidence (Ennis, 1985; Facione, 1990; Watson \& Glaser, 1990; Paul, 1992; Halpern, 1998);

- judging or evaluating (Ennis, 1985; Lipman, 1988; Facione, 1990; Watson \& Glaser, 1990; Case, 2005);

- making decisions or solving problems (Ennis, 1985; Halpern, 1998; Willingham, 2007);

- making inferences using inductive or deductive reasoning (Ennis, 1985; Facione, 1990; Watson \& Glaser, 1990; Paul, 1992; Willingham, 2007).

There were also other capibilities identified and relevant to critical thinking: answering questions for clarification (Ennis, 1985); defining terms (Ennis, 1985); identifying assumptions (Ennis, 1985; Paul, 1992); interpreting and explaining (Facione, 1990); predicting (Tindal \& Nolet, 1995); seeing both sides of an issue (Willingham, 2007) and others. 
The majority of scientists believe that the definition of critical thinking should also contain some dispositions. Lai (2011) identified these:

- open-mindedness (Bailin et al., 1999; Ennis, 1985; Facione, 1990, Halpern, 1998);

- propensity to seek reason (Bailin et al., 1999; Ennis, 1985; Paul, 1992);

- the desire to be well-informed (Ennis, 1985; Facione, 1990);

- flexibility (Facione, 1990; Halpern, 1998);

- respect for, and willingness to entertain, others' viewpoints (Bailin et al., 1999; Facione, 1990) and others.

All the mentioned components are results of several year interdisciplinary exploration, experimentation and searching for limits in the given area. In the conditions of Slovakia there does not exist a discussed comprehensive definition of critical thinking as a result of experimental verification of this ability in educational practice. The definitions we encounter in scientific literature in Slovakia come from well-known foreign experts, mostly without a critical analyses, opinions or inclinations to this definition. However, despite the absence of the comprehensive processing of critical thinking issues on the theoretical, methodological and application levels in the conditions of Slovakia, the development of this capability has become one of the fundamental challenges not only of SEP SR. There is also absence of specific guidelines saying how the issue should be processed nationwide - undergraduate studies, education in schools, continuing learning, etc. With the exception of studies of Petrasová (2003; 2008), Kosturková (2012; 2013a; 2016), Velmovská (2014) and those who cooperate directly with the Orava Association. The mentioned experts represent, unfortunately, only a few rare efforts.

Extensive analyses of several hundreds of foreign studies and selected models led to an attempt to create a programme of critical thinking development in the subject of Slovak language and literature. The entire process of critical thinking, from waking up the pupil's interest, through the contact with initial information, to the relevant argument of the decision taken, is perceived as very demanding and divided into several mental operations. It is also necessary to emphasize metacognition. In the context of critical thinking, Čavojová (2016) interpreted it rather clearly. According to the author metacognition (i.e. knowledge of own learning) is important as it allows people to monitor their own thinking processes.

Critical thinking thus appears to be a complex activity built from other skills that are easier. Van Gelder (2005) has given an example that if we want to respond to a newspaper article, we need to be able to understand the text, which assumes the ability to recognize its words, etc. If a knowledge base or skill is absent at lower levels, critical thinking will not happen. Even if the lower level skill has been mastered, it has to be combined in the right way. 
From our point of view, critical thinking is a complex process of thought operations that is built on the knowledge base of a student; begins with his attitude to an idea / information and continues with an ability to work with the received information in broader contexts and comes to the conclusion by reasoning their decision with the ability to use elements of corrective and self-regulated thinking and learning. We believe that pupils can improve their critical thinking skills most effectively as long as they use their own activity to get involved in the critical thinking practice. If we want pupils to learn to think critically, critical thinking must be an explicit part of the school curriculum.

\section{Critical thinking in educational practice in Slovakia - research findings}

The encyclopedic model of teaching put the pupil in the role of a submissive performer of didactic instructions, which greatly suppressed his creativity and critical thinking. Germušková (2012) - the didactic expert of Slovak language and literature - states that the traditionally conceived teaching was dominated by stereotyped didactic methodology, where the area of critical thinking was absent. This is also reflected in the absence of empirical research in this area in Slovakia. Such a change occurred in the Slovak Republic in connection with the requirements of the learning society. Although the origin of critical thinking dates back to Socrates' times, in the Slovak educational field this capability was presented on theoretical level in 1994 through a grant of Kolláriková (1995) along with some experts from the University of Northern Iowa (Kurtis S. Meredith and Jeannie L. Steel). However, this type of thinking in the field of school practice in the Slovak Republic has not been dealt so far. We consider the OECD PISA International Testing Review to be a critical moment of interest in critical thinking. The analysis of the results pointed out that the biggest problems of Slovak 15-yearolds were caused by the need to apply their critical thinking. The other measurements in the three-year OECD PISA cycles 2006, 2009, 2012, 2015 also showed a continuing trend in the monitored component (NUCEM, 2016). According to the PISA knowledge levels of reading literacy, students who can think critically are able to work at level 4-6. The results of PISA 2015 show that approximately $17.4 \%$ of Slovak pupils reached this level. Level 6 requires pupils logically deduction, ability to perform a precise and detailed comparison; demonstrating a detailed understanding of one or more texts, etc. This level was reached by $0.2 \%$ of Slovak pupils (NUCEM, 2016).

OECD PISA analyses show Slovak pupils'shortage in knowledge. It is also necessary to note how much attention is paid to the development of this potential in educational practice in Slovakia.

A new conception of teaching Slovak language and literature is based on new educational objectives: cognitive competence - the ability to think critically, formulate and solve problems; communication competence - ability to formulate 
their own attitudes and to argue; social competence - ability to tolerate differences in views; intra-personal competence - the ability of self-regulation, their own value system (ŠPÚ, 2015a). These goals can not obviously be met by the classical encyclopedic model of teaching. While making a fundamental change of didactic concept of teaching target language the greatest emphasis is placed on the own creation of language performance, working with information, reading literacy, ability to argue, etc. From the point of view of the way of realization, a constructive approach is recommended, on the basis of which a pupil obtains his / her new knowledge, reconstructs, systematizes and generalizes. The reason for the development of critical thinking of secondary school students is also a new type of maturita examination (school-leaving examination) from Slovak language and literature, which expects the student's critical thinking (ŠPÚ, 2015b).

The results of diagnosing the level of critical thinking of pupils in the selected grammar schools are far below the average comparing with London grammar school students of the same age (Kosturková, 2013a). A much more serious finding is that below average results in critical thinking are also shown by their teachers (Kosturková, 2016). As a result, the development of critical thinking has become a part of the educational strategy in Slovakia, but at the level of its application the teaching approaches remain largely unchanged. This was also highlighted by Petrasová (2008). Attitudes of secondary school teachers in Prešov region showed that the most common terms to task their students are: list, characterize, identify, define. The tasks expecting students' higher cognitive abilities such as observe and consider, create and argue only occur occasionally in the practice of respondents (Kosturková, 2013b). Similar findings are found in older but also in recent researches (Mareš \& Křivohlavý, 1989; Zelina \& Zelinová, 1990; Gavora, 1990; Zelina, 1994; Fontana, 2003; Palenčárová, 2008; Zelina, 2016).

\section{Methodology}

The basic aim of the experiment is to investigate and compare the teaching process realized through the programme of development of critical thinking with traditionally conceived teaching process within the course of the Slovak language and literature in 1st grade of a four-year grammar school.

The Programme of the Development of Critical Thinking in the School Subject of Slovak Language and Literature (intervention variable) has been operationally defined as: a deliberate, systematic and intentional 5-month - development of critical thinking of students performed by a specially trained teacher within the school subject of Slovak language and literature taught 3 lessons a week.

Regarding the education, the emphasis has been placed on the changes of organization of forms and methods, the principles of active learning, teaching strategies and methods to develop critical thinking - reading comprehension, questioning and to answering in own words, thinking about a text, a picture and 
an idea, seeking arguments to support own opinion, the ability to accept a different opinion, the ability to create own idea schemes, the corrective thinking ability, etc.

Teaching Slovak language and literature was based on a complex communication model of teaching and learning - on the E-R-R strategy (evocation, realization of meaning, reflection). Within the individual parts of E-R-R the following methods developing critical thinking were used: Buzz Groups, Cinquain, Cloze Test, Clustering, Cubing, INSERT, Know-Want-Learned, Method of Questioning, Writing Works, Writing Here and Now, Mind mapping, Graphic postorganizers, Situational method, Snowballing, Socratic Dialogue, Six Good Servants, Six Hats, Think-Work in Pairs-Exchange Opinions, Venn's Diagram, Exchanging of Questions and Answers; Metacognitive Strategies (Reader Strategy 3-2-1, Strategy RAP - Read-Ask-Paraphrase, SQ3R - Survey-Question-ReadRecite-Review ); some lessons had a character of complex strategies: Cooperative Teaching, Problem Teaching and Project Teaching.

The Program of Development of Critical Thinking in the Subject of Slovak Language and Literature consisted of 20 literature lessons and 15 grammar lessons and contained 195 pages (teachers preparation and worksheets).

Critical thinking of a student (determined variable in position of dependent variable) was operationally defined as: gross score in the Watson-Glaser Critical Thinking Appraisal test (W-GCTA). The test consists of a series of five test areas (judgments, recognition of assumptions, deduction, interpretation and evaluation of arguments) with 16 points for each subtest. The whole test contains 80 tasks (Watson \& Glaser, 2000).

The available selection consisted of 16 classes of pupils of 1st grade of fouryear grammar schools in the Prešov and Košice regions. On the basis of input measurements of the level of critical thinking, two balanced groups were selected $(p=0.567623)$. The experimental group $(n=32)$ and the control group $(n=30)$ were randomly assigned by experimental conditions.

\section{Results and discussion}

The basic condition for realizing the true experiment was the question of choosing the equal groups (Kerlinger, 1972). Experimental groups underwent input measurements checking the level of critical thinking through W-GCTA (Watson \& Glaser, 2000). Table 1 presents an ante measurement result as well as a result showing the balance of both groups.

Based on the results of t-test comparing average (Table $1, p=0.572$ ) we can say that there was no statistically significant difference between the experimental and the control group in critical thinking in the ante situations $(p>0.05)$. The t-test showed the balance of both groups at the beginning of the experiment.

The intervention program of the development of critical thinking was applied via teaching three lessons a week during the second term of the school year 2012 
(i.e. 5 months). A plan of experiment and preparation for language literature training based on a complex communication model of teaching and learning E-U$\mathrm{R}$ was prepared in advance.

Tab. 1: Balance of the groups based on ante measurements

\begin{tabular}{|c|c|c|c|c|c|c|}
\hline \multicolumn{7}{|c|}{$\begin{array}{l}\text { t-test; } \\
\text { EG - experimental group }(n=32) \\
\text { CG - control group }(n=30)\end{array}$} \\
\hline \multirow[t]{2}{*}{$\begin{array}{l}\text { Gross } \\
\text { score }\end{array}$} & $\begin{array}{l}\text { EG } \\
\text { Average } \\
\text { (M) }\end{array}$ & $\begin{array}{l}\mathrm{EG} \\
(S D)\end{array}$ & $\begin{array}{l}\text { CG } \\
\text { Average } \\
\text { (M) }\end{array}$ & $\begin{array}{l}\text { CG } \\
(S D)\end{array}$ & $t$ & $p$-value \\
\hline & 41.75 & 4.90 & 41.03 & 3.5 & 0.567623 & 0.572409 \\
\hline
\end{tabular}

Key: $n$ - number; $S D$ - standard deviation; $t$ - result of $t$-test

The choice of the E-U-R strategy was targeted as it respects the current knowledge of psychological research on how people usually learn. It is one of the specific approaches of pedagogical constructivism, i.e. a pupil does not obtain the ready knowledge, but has to create it based on his / her experience and the knowledge acquired earlier (Maňák \& Švec, 2003). A great emphasis was placed on the ability to argue and ask questions. The development of critical thinking was only happening in the experimental group. The teaching of Slovak language and literature in the control group took place in the intentions of traditional teaching (encyclopedic-memorization approach). The results of the 5-month- experiment on the development of critical thinking are presented in Table 2.

Comparing the level of critical thinking in the experimental group at the beginning of the experiment $(M=41.75, S D=4.90)$ and at the end of the experiment $(M=43.96, S D=4.57)$ showed a significant difference at a level of significance 0,01 . Based on the result of t-test ( $p=0.001481$ ) it can be concluded that the impact of the intervention programme of the development of critical thinking during the lessons of Slovak language and literature in the post-test has been reflected in an increased level of critical thinking of students. In the control group the one without the intervention programme, no increase in the level of critical thinking of students $(p=0.83)$ has been detected.

Statistical t-test (Table 3) confirmed our assumption that the application of the Program of Development of Critical thinking in Teaching the Subject Slovak Language and Literature causes an increase of the level of critical thinking of students in the experimental group comparing to the traditionally performed teaching method of the subject in the control group. 
Tab. 2: T-test for dependent samples

\begin{tabular}{|c|c|c|c|c|c|c|}
\hline \multicolumn{6}{|c|}{$\begin{array}{l}\text { EG - experimental group }(n=32) \\
\text { CG - control group }(n=30) \\
\text { Marked correlations are significant at the level } p<0.05\end{array}$} & \\
\hline & $M$ & $S D$ & difference & $\begin{array}{l}\text { SD } \\
\text { differe } \\
\text { nce }\end{array}$ & $t$ & $p$-value \\
\hline $\begin{array}{l}\text { Gross } \\
\text { score } \\
\text { ante } \\
\text { CG }\end{array}$ & 41.03 & 5.03 & \multirow{2}{*}{0.100000} & \multirow{2}{*}{2.66} & \multirow[b]{2}{*}{0.205158} & \multirow[b]{2}{*}{0.838882} \\
\hline $\begin{array}{l}\text { Gross } \\
\text { score } \\
\text { post } \\
\text { CG }\end{array}$ & 40.93 & $\begin{array}{l}5.2 \\
9\end{array}$ & & & & \\
\hline $\begin{array}{l}\text { Gross } \\
\text { score } \\
\text { ante } \\
\text { EG }\end{array}$ & 41.75 & $\begin{array}{l}4.9 \\
0\end{array}$ & \multirow{2}{*}{-2.21875} & \multirow{2}{*}{3.59} & \multirow{2}{*}{-3.48769} & \multirow[b]{2}{*}{0.001481} \\
\hline $\begin{array}{l}\text { Gross } \\
\text { score } \\
\text { post } \\
\text { EG }\end{array}$ & 43.96 & $\begin{array}{l}4.5 \\
7\end{array}$ & & & & \\
\hline
\end{tabular}

Key: $n$ - number; $M$ - average; $S D$ - standard deviation; $t$ - result of $t$-test

Tab. 3: T-test comparing average figures of the W-GCTA posttest in EG and CG

\begin{tabular}{|c|c|c|c|c|c|c|}
\hline \multicolumn{7}{|c|}{$\begin{array}{l}\text { t-test; } \\
\text { EG - experimental group }(n=32) \\
\text { CG - control group }(n=30)\end{array}$} \\
\hline \multirow[b]{2}{*}{$\begin{array}{l}\text { Critical } \\
\text { Thinking } \\
\text { Level - } \\
\text { Posttest }\end{array}$} & $\begin{array}{l}\text { EG } \\
\text { (M) }\end{array}$ & $\begin{array}{l}\text { CG } \\
(M)\end{array}$ & $t$ & $p$-value & $\begin{array}{l}\text { EG } \\
(S D)\end{array}$ & $\begin{array}{l}\text { CG } \\
(S D)\end{array}$ \\
\hline & 43.96 & 40.93 & 2.419001 & 0.018613 & 4.57 & 5.29 \\
\hline
\end{tabular}

Key: $n$ - number; $M$ - average; $S D$ - standard deviation; $t$ - result of $t$-test

Our findings from the experimental research coincide with a number of results by predominantly foreign authors who have come to the conclusion that critical thinking can be developed by targeted training (compare Hill, 1959; Ennis, 1962; 
Glaser, 1963; Sternberg, 1987; Facione, 1990; Gavora, 1995; Petrasová, 2008; Marin \& Halpern, 2011 and others).

The authors of W-GCTA define critical thinking as a combination of attitude, knowledge and ability (Watson \& Glaser, 2000), with which we agree. Our experience with the application of the intervention programme helped us specify components that should not be underestimated. One of the most challenging tasks in developing of such a key competence, as Bean (1996) called it, was awakening pupils' awareness of a particular problem. We called it "be open to new knowledge". An important element in solving a given question or problem is a knowledge base (Kolláriková, 1995). In our case it is the learning content of Slovak language and literature in a grammar school type of study. Contact with a new idea or information is conditioned by the ability to think about it, to consider its credibility (i.e. to understand its meaning in broader contexts). It is necessary to include information reassessment activities - what I know about it, what I have learned, how I can put it in different contexts and how I can work on with it. When applying knowledge to solve the problem a pupil often encounters obstacles and limitations resulting from the lack of knowledge. Piaget (1970) calls this a cognitive conflict. It is possible for the pupil to overcome it through actions such as analysis, reviewing the information and arguments ${ }^{1}$, search for new solutions, which we can name the corrective thinking (interpretation, analyzing, comparison, designing own criteria, evaluation, or other information). Using the Socrates Dialogue or Question Method are just a few methods we recommend to involve pupils in these complex thinking processes. This fact is confirmed by e.g. Marzano (1997), Tallent \& Barnes (2015). Using the Socratic Method the pupils can learn how to find their own solutions using the quality critical thinking. The result of this process is the reconstruction and systematization of the newly acquired knowledge on a qualitatively higher level.

In our program, methods have been largely used to make pupils think about the problem deeper, put analytical, hypothetical and evaluative questions; look for arguments, reasons and evidence for their opinions; anticipate consequences, etc. At the beginning of the experiment the pupils of the experimental group had a big problem getting into the depths of the problem. Cimermanová (2014) also pointed out this issue when teaching foreign languages by reading pictures. The author recommends a method of reading pictures because it helps pupils get more involved, develops their imagination and forces them to think more deeply.

In the educational system of countries that have reached the first place in reading literacy (Shanghai-China, Singapore, Hong Kong, China, Taiwan, Korea), a great emphasis is placed on the development of critical thinking and creativity

1 The argument consists of three basic items: the claim that is supported by reasons and every reason is supported by evidence (Klooster, 2000). 
through motivation and active involving pupils in various research tasks (Bagalová, Bizíková, \& Fatulová, 2014), in sharp contrast with the Slovak education system, as evidenced by the above-mentioned OECD PISA analysis and the diagnosed level of critical thinking. According to Knapík (2013a, 2013b) the opportunity to develop pupils' critical thinking can be realized by removing passivity in teaching. Smetanová et al. (2014) mentions activities developing pupils' argumentation skills, ability to evaluate situations and their own performance connected with feedback and self-reflection. The importance of selfreflection is preferred by several authors, e.g. Petríková (2015); Knapík (2014, 2015); Pavlov (2015); Petrasová (2016); Zelina (2016); Šutáková \& Ferencová (2017) and others. Černotová \& Ištvan (2015) understand the effectiveness of development of critical thinking through cooperative education, which has also been confirmed by us.

The realized experiment is one of the first attempts to verify the development of critical thinking in the process of teaching Slovak language and literature in Slovak grammar schools. We recommend implementation of critical thinking in the curriculum, as the given competency has been identified by leading experts as one of the basic education and innovation skills required for life and practice in the 21st century.

\section{Conclusion}

One of the main goals of education, at any level, is to contribute to the development of the general thinking of pupils, including their ability to think critically. The starting point of elaborating and experimental verification of The Programme of the Development of Critical Thinking in Teaching Slovak Language and Literature was the absence of empirical knowledge about the development of this capability in conditions of Slovak secondary schools ,identified below average state of critical thinking of Slovak grammar school students and recurrent failure of Slovak 15-year-olds in international OECD PISA measurements in reading literacy (component - assessment and thinking about the text). The conclusions of the 5-month- intervention programme have produced positive results, although significant problems have been detected at the beginning of the experiment. Initially, pupils had a great difficulty in finding arguments supported by reasoning and evidence, since innovative way of teaching required new ways of their thinking. Therefore we recommend the following: begin with easier methods to develop critical thinking; leave the pupils a room to complete a task linked with feedback; to give the pupils a problem based on practical experience in accordance with a subject topic; make questions related to the level of higher thought processes and look for answers using the Socratic Method; to give pupils space to think, discuss and argue, etc. 
Despite the fact that the development of critical thinking is included into the National Educational Programme of the Slovak Republic as one of its target requirements, in our conditions it is a unsystematic development of this capability in secondary schools.

By the findings resulting from the experimental verification of the critical thinking in the teaching process of Slovak language and literature we wanted to create a space for better support for the education of pupils to think critically. Taking into account the needs of the society, we recommend the elabotating of continuing education programmes for teachers as well as changing the system of pre-gradual training for the teaching profession.

At the conclusion we can state that empirical research of critical thinking in Slovak conditions is a difficult and unexplored issue - in other words, in our conditions a rather new phenomenon. The results of our experimental research open up space for an expert discussion. The fact is that critical thinking is considered the most desirable quality of the person of the future, so Slovak schools should become centers where the content of education is the starting point of thinking not its results.

\section{Acknowledgment}

This article presents partial findings collected while working on project VEGA 1/0382/16 Inovatívna kultúra školy ako učiacej sa organizácie that is supported by Ministry of Education, Science, Research and Sport of the Slovak Republic.

\section{References}

Bagalová, L'., Bizíková, L., \& Fatulová, Z. (2014). Komparatívna analýza vzdelávacieho systému v Slovenskej republike a vo vybraných ázijských krajinách. Bratislava: ŠPÚ.

Bailin, S. R. et. al. (1999). Conceptualizing critical thinking. Journal of Curriculum Studies, 31(3), 285-302.

Bean, J. C. (1996). Engaging Ideas - The Professor's Guide to Integrating Writing: Critical Thinking and Active Learning in the Classroom. San Francisco: JosseyBass.

Case, R. (2005). Moving critical thinking to the main stage. Education Canada, 45(2), 45-49.

Cimermanová, I. (2014). Graphic Novels in Foreign Language Teaching. Journal of Language and Cultural Education, 2(2), 85-94.

Čavojová, V. (2016). 0 čom je reč, ked' hovoríme o racionalite a kritickom myslení. In Čavojová, V. et al. (Eds.), Rozum: návod na použitie. Psychológia racionálneho myslenia. (s. 69-87). Bratislava: Iris. 
Černotová, M., \& Ištvan, I. (2015). Kooperatívne vyučovanie v teórii a praxi. Edukácia, 1(2), 75-87.

Ennis, R. H. (1962). A concept of critical thinking. Harvard Educational Review, 32(1), 81-111.

Ennis, R. H. (1985). A logical basis for measuring critical thinking skills. Educational Leadership, 43(2), 44-48.

Facione, P. A. (1990). Critical thinking: A statement of expert consensus for purposes of educational assessment and instruction: Research findings and recommendations. Fullerton: California State University.

Fontana, D. (2003). Psychologie ve školskí praxi. Praha: Portál.

Gavora, P. (1990). Teacher's questions. Scientia Paedagogica Experimentalis, 27(2), 283-293.

Gavora, P. (1995). Kritické myslenie - prehl’ad situácie v zahraničí. In Z. Kolláriková (Ed.), Výchova ku kritickému mysleniu (s. 7-22). Bratislava: ŠPÚ.

van Gelder, T. (2005). Teaching critical thinking: some lessons from cognitive science. College Teaching, 53(1), s. 41-46.

Germušková, M. (2012). Oponentský posudok. Prešov: Prešovská univerzita $\mathrm{v}$ Prešove.

Glaser, E. M. (1963). An experiment in the development of critical thinking. Michigan: State University.

Halpern, D. F. (1998). Teaching critical thinking for transfer cross domains: Dispositions, skills, structure training and metacognitive monitoring. American Psychologist, 53, 449-455.

Hill, W. H. (1959). Watson-Glaser critical thinking appraisal. In O. K. Buros (Ed.), The Fifth Mental Measurements Yearbook. (pp. 796-797). Highland Park: Gryphon Press.

Kerlinger, F. N. (1972). Základy výzkumu chování. Praha: Academia, nakladatelství ČSAV.

Klooster, D. (2000). Co je kritické myšlení? Kritické listy, 1(1), 1-2. Retrieved from http://www.kritickemysleni.cz/klisty.php?co=klisty2_cojeKM

Kolláriková, Z. (1995). Model kritického myslenia a zásady jeho rozvoja. In Kolláriková, Z. (Ed.), Výchova ku kritickému mysleniu: teória a prax (s. 23-42). Bratislava: PF.

Kosturková, M. (2012). Možnosti využitia stratégie E-U-R v edukácii. Pedagogické rozhl'ady, 21(1-2), 1-5.

Kosturková, M. (2013a). Stav kritického myslenia žiakov stredných škôl. Didaktika, $4(2), 11-15$.

Kosturková, M. (2013b). Uplatnenie humanistických myšlienok J. A. Komenského v súčasnej praxi pedagógov. In Belácová, L'. \& Portik, M. (Eds.), Jan Amos Komenský a súčasná predškolská a elementárna edukácia (s. 217-227). Prešov: Prešovská univerzita v Prešove. 
Kosturková, M. (2016). Kritické myslenie v edukačnej praxi na Slovensku. Prešov: Rokus.

Knapík, J. (2013a). Inovatívne metódy v predmet NV. In Jenčo, J. (Ed.), Inovačné vyučovacie metódy (s. 47-54). Prešov: Michal Vaško.

Knapík, J. 2013b). Demokratická klíma v triede - dôležitý faktor pri výchove žiakov. Vychovávatel', 62(3-4), 19-22.

Knapík, J. (2014). Dramatická výchova vo vyučovaní. In Jenčo, J. \& Genčúrová, G. (Eds.), Inovačné vyučovacie metódy a ich aplikácia do náboženskej výchovy (s. 181-203). Prešov: Michal Vaško.

Knapík, J. (2015). Hodnotenie štúdia na teologickej fakulte bežnými študentmi. In Danielová, L. \& Linhartová, D. (Eds.), Proceedings of international scientific conference ICOLLE 2015 (s. 281-291). Brno: Mendelova univerzita v Brne.

Lai, E. R. (2011). Critical thinking: A literature review. Retrieved from http://images.pearsonassessments.com/images/tmrs/CriticalThinkingRevie wFINAL.pdf

Lipman, M. (1988). Critical Thinking: What Can It Be? Educational Leadership, 46(9), 38-43.

Maňák, J., \& Švec, V. (2003). Výukové metódy. Brno: Paido.

Mareš, J., \&Křivohlavý, J. (1989). Sociální a pedagogická komunikace ve škole. Praha: SPN.

Marin, L. M., \& Halpern, D. F. (2011). Pedagogy for developing critical thinking in adolescents: Explicit instruction produces greatest gains. Thinking Skills and Creativity, (6), 1-13.

Marzano, J. R. et al. (1997). Dimensions of Learning: Teachers Manual (2th ed.). USA: MCREL.

NÚCEM. (2016). Výsledky PISA - výzva pre skvalitnenie slovenského školstva. Retrieved from http://www.nucem.sk/documents/27/medzinarodne_merania/pisa/publika cie_a_diseminacia/4_ine/Prve_vysledky_Slovenska_v_studii_OECD_PISA_201 5.pdf

Palenčárová, J. (2008). K čítaniu ako komunikačnej zručnosti. Retrieved from http://www.files.janapale.webnode.sk/20000001377fb578f81/9\%20_CITANIE.pdf

Paul, R. W. (1992). Critical thinking: What, why, and how? New Directions for Community Colleges, (77), 3-24.

Pavlov, I. (2015). Determinanty kvality lektorov v profesijnom rozvoji učitel'ov. Edukácia, 1(1), 217-224.

Petrasová, A. (2003). Využitie E-U-R ako prostriedku eliminácie funkčnej negraotnosti rómskych žiakov. Prešov: PF PU.

Petrasová, A. (2008). Kriticky mysliaci učitel' - tvorca kvality školy. Prešov: Rokus. 
Petrasová, A. (2016). Spôsobilost' kriticky mysliet' ako determinant reflexívneho charakteru súvislej výučbovej praxe (s. 69-73). Prešov: PF Prešovská univerzita v Prešove.

Petríková, K. (2015). Alternatívne prístupy k pedagogickému hodnoteniu vo vyučovacom procese. Edukácia, 1(2), 115-124.

Piaget, J., \& Inhelderová, B. (1970). Psychologie dítěte [Piaget, 1970]. Praha: SPN.

Smetanová, V. et al. (2014). Implicit theories of critical thinking in teachers and future teachers. Procedia - Social and Behavioral Sciences, (171), 724-732.

Sternberg, R. J. (1987). Teaching critical thinking: Eight easy ways to fail before you begin. Phi Delta Kappa, 68, 456-459.

ŠPÚ. (2015a). State Education Programme of the Slovak Republic: Introduction. Retrieved from http://www.statpedu.sk/clanky/statny-vzdelavaciprogram/uvod

ŠPÚ. (2015b). State Education Programme of the Slovak Republic: ISCED 3A. Retrieved from http://www.statpedu.sk/sites/default/files/dokumenty/statny-vzdelavaciprogram/isced3_spu_uprava.pdf

Šutáková, V., \& Ferencová, J. (2017). Komparácia didaktických spôsobilostí študentov učitel'stva a učitel'ov v pedagogickej praxi. Edukácia, 2(1), 313-322.

Tallent, R. J., \& Barnes, J. J. (2015). Think bubbles and Socrates: teaching critical thinking to millennial in public relations classes. Universal Journal of Educational Research, 3(7), 435-441.

Tindal, G., \& Nolet, V. (1995). Curriculum-based measurement in middle and high schools: Critical thinking skills in content areas. Focus on Exceptional Children, 27(7), 1-22.

Velmovská, K. (2014). Physics mistakes in movies or the possibility of developing critical thinking in physics education. Journal of science education. 15(1), 3740.

Watson, G., \& Glaser, E. M. (1990). Watson-Glaser critical thinking appraisal. GB: Psychological corporation.

Watson, G., \& Glaser, E. M. (2000). Watson-Glaserový test hodnotenia kritického myslenia. Bratislava: Psychodiagnostika.

Willingham, D. T. (2007). Critical thinking: Why is it so hard to teach? American Educator (s. 8-19). Retrieved from:

https://www.uvm.edu/ facsen/generaleducation/Critical\%20Thinking\%20 Article\%20-\%20Willingham.pdf

Zelina, M., \& Zelinová, M. (1990). Rozvoj tvorivosti detí a mládeže. Bratislava: SPN. Zelina, M. (1994). Stratégie a metódy rozvoja osobnosti diet'at'a. Bratislava: Iris.

Zelina, M. (2016). L'udské kvality pre budúcnost'. Pedagogická revue, 63(1-2), 1412. 


\section{Contact}

PhDr. PaedDr. Martina Kosturková, PhD.

University of Prešov in Prešov

the Faculty of Humanities and Natural Sciences

Department of Pedagogy

17. novembra 1

08016 Prešov

Slovakia

martina.kosturkova@unipo.sk 